\title{
Retrospective Evaluation of Surgical Methods and Outcomes of Pediatric Nasolacrimal Duct Obstruction According to Age Groups
}

\author{
Yaș Gruplarına Göre Pediatrik Nazolakrimal Kanal Tıkanıklığının Cerrahi Yöntem ve \\ Sonuçlarının Retrospektif Olarak Değerlendirilmesi
}

\author{
Șule Çınar', Ali Șimșek', Ali Asgar Yetkin', Lokman Balyen² \\ ${ }^{1}$ Adryaman University, Faculty of Medicine, Department of Ophthalmology, Adiyaman; ${ }^{2}$ Kafkas University Faculty of Medicine, \\ Department of Ophthalmology, Kars, Türkiye
}

\section{ABSTRACT}

Aim: To evaluate the outcomes of different surgical methods in nasolacrimal duct obstruction (NLDO) in pediatric patients according to age groups.

Material and Method: Patients with NLDO were included in the study. Records of patients who underwent nasolacrimal duct (NLD) probing, silicone tube intubation or endoscopic dacryocystorhinostomy (DCR) for congenital nasolacrimal duct obstruction (CNLDO) or acquired NLDO between 2015 and 2018 were retrospectively reviewed. The age of the patients during the surgery, the status of postoperative watering complaints and the presence of epiphora were analyzed according to age groups.

Results: Of 150 patients, $77 / 150$ (51.3\%) were female, 73/150 (48.7\%) were male. The mean age of patients was 22.3 (1 month-8 years) months. In this study, 174 eyes of 150 patients with NLDO were included. Patients were divided into four groups in terms of age groups at the time of admittance. A hundred percent of the first group (0-12 months) was treated successfully with the NLD probing. However, in the second group (12-24 months), the success rate was $81.8 \%$ with the NLD probing. In the third group (24-48 months), the success rate of NLD probing decreased to $52.4 \%$, while the success rate of silicone tube intubation was $100 \%$ in the same age group. In the fourth group (48 months or over), the success rate of NLD probing decreased to $20 \%$, while all procedures performed with endoscopic DCR and silicone tube intubation were successful.

Conclusion: Pediatric patients with NLDO, the choice of the treatment procedure and the success rate of treatment vary according to age group. NLD probing procedure is a safe and effective treatment method for CNLDO in cases that are unresponsive to conservative treatment in the first 12 months of life. As the patients' age increases, the success of the NLD probing decreases. However, prior to an invasive treatment modality, NLD probing procedure is recommended more than one time.

Key words: endoscopic dacryocystorhinostomy; pediatric nasolacrimal duct obstruction; probing; silicon tube intubation

\section{ÖZET}

Amaç: Pediatrik hastalarda nazolakrimal kanal tıkanıklığında (NLKT) farklı cerrahi yöntemlerin sonuçlarını yaș gruplarına göre değerlendirmek.

Materyal ve Metot: Çalıșmaya NLKT tanısı alan hastalar dâhil edildi. Doğumsal nazolakrimal kanal tıkanıkı̆̆ı (DNLKT) veya edinsel NLKT nedeniyle 2015-2018 yılları arasında nazolakrimal kanal (NLK) sondalama, silikon tüp entübasyonu veya endoskopik dakriyosistorinostomi (DSR) yapılan hastaların kayıtları geriye dönük olarak incelendi. Ameliyat sırasındaki hastaların yașı, ișlem sonrası sulanma șikayetlerinin durumu ve epifora varlı̆̆ı yaș gruplarına göre analiz edildi.

Bulgular: Çalıșmaya alınan 150 hastanın 77/150'si (\% 51,3) kadın, 73/150'si (\% 48,7) erkekti. Hastaların yaș ortalaması 22.3 (1 ay-8 yıl) aydı. Çalıșmaya NKLT tanısı alan 150 hastanın 174 gözü dahil edildi. Hastalar bașvuru sırasındaki yaș grupları açısından dört gruba ayrıldı. Birinci grubun yüzde 100'ü (0-12 ay) NLK sondalama ile bașarılı bir șekilde tedavi edildi. Bununla birlikte, ikinci grupta (1224 ay) NLK sondalama ile bașarı oranı \% 81.8 idi. Üçüncü grupta (24-48 ay) NLK sondalamanın bașarı oranı \% 52.4'e düșerken, silikon tüp entübasyon bașarı oranı aynı yaș grubunda \% $100 \mathrm{idi}$. Dördüncü grupta (48 ay veya daha büyük) NLK sondalamanın bașarı oranı \% 20'ye düșerken, endoskopik DSR ve silikon tüp entübasyonuyla yapılan tüm operasyonlar bașarılı olmuștur.

Sonuç: Nazolakrimal kanal tıkanıkı̆̆ı olan pediatrik hastalarda tedavi prosedürünün seçimi ve tedavinin bașarı oranı yaș grubuna göre değișmektedir. NLK sondalama prosedürü, yașamın ilk 12 ayında konservatif tedaviye yanıt vermeyen durumlarda DNLKT için güvenli ve etkili bir tedavi yöntemidir. Hastaların yașı arttıkça, NLK sondalama bașarısı azalır. Bununla birlikte, invaziv bir tedavi yönteminden önce, NLK sondalama prosedürü bir kereden fazla yapılması önerilmektedir.

Anahtar kelimeler: endoskopik dakriyosistorinostomi; pediatrik nazolakrimal kanal tıkanıklı̆ı̆; sondalama; silikon tüp entübasyon

IIetișim/Contact: Sule Cinar, Adivaman University, Faculty of Medicine, Department of Ophthalmology, Adryaman, Türkiye • Tel: 05056809926 • E-mail: ssulecinar@gmail.com • Geliș/Received:26.04.2019 • Kabul/Accepted:27.12.2019

ORCID: Şule Çınar, 0000-0001-8377-0753 • Ali Şimşek, 0000-0002-5077-8721 • Ali Asgar Yetkin, 0000-0002-4825-0004 • Lokman Balyen, 0000-0003-4298-7256 


\section{Introduction}

Congenital nasolacrimal duct obstruction (CNLDO) is a prevalent condition in the pediatric age group, causing failure in the nasolacrimal duct drainage system, and hence overflow of tears, also called epipho$\mathrm{ra}^{1,2}$. It has been reported with epidemiological studies that the prevalence of CNLDO varies between 5\% and $20 \%$ in early childhood and it often improves without surgery ${ }^{2,3}$. The CNLDO is the most common cause of persistent epiphora in the pediatric population. The clinical presentation of CNLDO is frequently characterized by extreme watering of the eye. The distal obstruction at the Hasner valve causes a mucopurulent discharge, yet it is manifested by a watery discharge when the obstruction is near the nasolacrimal sac (Rosenmüller valve) ${ }^{2,4,5}$. Infants present with persistent tear overflow or mucoid discharge from the eyes due to CNLDO, resulting in periocular and ocular infections, such as maceration and irritation of the skin and conjunctivitis ${ }^{5}$. The CNLDO is caused by the delay in the formation of the valve at the distal nasolacrimal duct (Hasner's valve) ${ }^{3,6}$. After birth, it is known that it is opened spontaneously and reported that $70 \%$ of the cases were spontaneously opened within the first 3 months and as much as $96 \%$ opened in the first year ${ }^{3,6}$. Various treatment options for NLDO are available, including conservative treatments, such as observation (or postponed of the probing) and massage of the lacrimal sac with antibiotic ointment. Conservative treatments are recommended before invasive methods in the first year of life ${ }^{7}$. The treatment preference and the success of the preferred treatment are dependent on the age of patients. It has been reported in many studies that the nasolacrimal duct (NLD) probing has a high success rate in the first year of life. However, success rate decreases with increasing age ${ }^{8,9}$. If the watering continues and the patients older than 1 year and unresponsive to conservative treatment, the NLD probing should be performed ${ }^{7}$. Nevertheless, NLD probing should be also performed prior to the first year of life in cases that patients with frequent infections or in the presence of dacryocystocele ${ }^{7}$. It has been reported that complications such as acute cellulitis, lacrimal abscess, dacryocystitis may be seen in case of delayed probing ${ }^{10}$. Besides, fibrosis-related to inflammation and trauma which is the result of frequent infection also rarely causes $\mathrm{NLDO}^{5}$. The NLD probing is generally performed under general anaesthesia in the operating room. NLD probing may resolve the symptoms by opening the membranous obstruction into the distal NLD; however, it may fail when the obstruction is caused by bony protrusion into the NLD or if the NLD is edematous due to dacryocystitis. Additionally, there are many potential local complications associated with probing, including the creation of a false passage and bleeding, as well as injury to the nasolacrimal duct, canaliculi, and puncta ${ }^{5}$. The aim of this study was to report our experience in the treatment of pediatric NLDO patients according to age groups.

\section{Materials and Methods}

The methods and results of treatments that were applied to 174 eyes of 150 children with NLDO, who applied to Adiyaman University Faculty of Medicine Eye Clinic with the complaints of epiphora and discharge from the eye, were evaluated retrospectively from hospital records. This investigation adhered to the tenets of the World Medical Association Declaration of Helsinki. The study protocol and consent procedures were approved by the Institutional Review Board of the Adiyaman University Faculty of Medicine Ethics Committee (approval no. 2018/8-24). Descriptive analyses were performed for the groups to determine the success rate of the treatment. All parents or guardians of the children were informed about the nature and possible complications of treatment and informed consent was obtained from the parents or guardians of the children. The detailed medical history of the patients was also questioned.

Records of patients who underwent NLD probing, silicone tube intubation or endoscopic dacryocystorhinostomy (DCR) for CNLDO or acquired NLDO between 2015 and 2018 were retrospectively reviewed. The age of the patients during the surgery, the status of postoperative watering complaints and the presence of epiphora were analyzed according to age groups. Patients were divided into 4 groups depending on their age at the time of surgery; the first group of 0-12 months (61 eyes, $35.1 \%$ ), the second group of 13-24 months (77 eyes, $44.3 \%$ ), the third group of $25-48$ months (24 eyes, $13.8 \%$ ) and the fourth group of 48 months (12 eyes, 6.9\%). The patients were followed for an average of 18 months (12-24 months). The first and second group patients who could not benefit from conservative treatment and those who had not formerly been received any treatment but had dacryocystocele under 1 year of age were applied to the probing at least twice. In the third and fourth groups, patients who had not previously been applied to the probing before, or 
previously applied to unsuccessful probing, were also applied to the probing prior to more invasive surgery. Silicone tube intubation was performed in the patients in the third and fourth groups who had been applied to unsuccessful probing and whose family approval was obtained. Endoscopic DCR was performed in patients older than seven years.

Probing was performed under general anaesthesia (laryngeal mask) at the operating room conditions. Following the lower and upper punctum dilatation with a punctal dilator, irrigation was performed through the lower or upper punctum using an irrigation cannula attached to a syringe to determine whether the nasolacrimal system was open. Then the metal probe was inserted perpendicular to the lower or upper eyelid margin of the punctum and advanced into the ampulla. The probe was slightly rotated horizontally into either the lower or upper. When the nasal wall of the sac was reached and a hard stop was felt, the probe was rotated 90 degrees and directed downward through the nasolacrimal canal into the nasal cavity. When membrane rupture was felt, the catheter was retracted, then the nasolacrimal duct patency was confirmed by intraoperative irrigation using fluorescein dye. Fluorescein staining of the applicator cotton placed on the lower meatus was observed and the patency of the passage was checked. Topical antibiotics drops and low-dose topical steroids were prescribed four times daily for 1 week after the procedure. In the controls, the parents were asked whether the complaint of watering persisted, and the ophthalmologic examinations of the patients were performed. In the absence of the complaint of watering and in the absence of epiphora at the examination, probing was considered as successful.

Silicon tube intubation (Visitec 5011) was applied to patients aged 24-48 months in which probing failed. Under general anaesthesia, the punctum was dilated first and the metal tip at the end of the silicone tube was inserted through the upper and lower punctum. The metal probes at the end of the tubes were removed from the nostril by means of a toothless forceps. The metal parts were separated from the silicone tubes and the tubes were connected to each other and left untouched to the nasal cavity. The tubes were left in place for 3-6 months and the parents were informed about this procedure. Postoperatively, topical combined antibiotic-steroid drops, oral antibiotics and nasal decongestant pediatric spray were prescribed four times daily for 1 week.
Endoscopic DCR was performed to children older than seven years. Preoperative computed tomography imaging was performed prior to endoscopic DCR surgery. After general anaesthesia, vasoconstriction was provided with $0.1 \%$ adrenaline in the nasal mucosa. Endoscopic evaluation of the nasal cavity was performed by injecting a local anaesthetic (Jetokain) solution into the inferior concha to expand the nasal cavity. Medial concha axillary, maxillary line was determined. One end of the bayonet pliers was advanced in the nasal cavity, followed by the lateral nasal wall. The outside tip was brought closer to each other in the region corresponding to the projection. A local anaesthetic solution was injected into the mucosa, which was projected around $1 \mathrm{~cm}$ upper and anterior pouch of the maxillary line, which contacted the lateral wall of the nose of the bayonet pliers. The mucosa incision was made with a sickle knife and the mucoperiosteal flap was removed from the bone tissue by Freer elevator and the mucosa was removed from the field. In the lateral nasal wall, mucoperiosteal tissue similar to a circle containing the mucosa and periosteum extending 2-3 $\mathrm{cm}$ above the medial concha head adhesion and up to the anterior border of uncinate process at the back was removed. Bone was removed with Kerrisons straight and curved punches to expose the lacrimal sac. A bone window $(10 \times 15 \mathrm{~mm})$ was opened with Kerrison forceps. After dilatation of the punctum, the bicanalicular lacrimal duct silicone tube intubation was performed. The tubes were separated from the metal pieces and the tubes were tied inside the nose and placed in the nasal cavity without being sutured to the nasal wall. The nasal cavity was filled with ointment gauze to prevent bleeding. In the postoperative period, all patients were discharged the following day on topical combined antibiotic-steroid drops, oral antibiotics and nasal decongestant pediatric spray. Besides, parents were also informed that the tubes would remain in the nasal cavity for at least three months and at most six months.

\section{Statistical Analysis}

Retrospectively data were collected for gender, age at intervention, demographic and clinical features. The procedure was considered successful when all symptoms associated with NLDO, such as discharge and irrigation, disappeared postoperatively. Data were collected, reviewed and stored in a Microsoft Access (V.2007) database (Microsoft Corp, Redmond, Washington, USA). Statistical analysis was performed with SPSS V.18.0 (SPSS Inc, Chicago, IL, USA). 
Descriptive analyses were performed for groups to evaluate the association between potential risk factors, failure and the success rate of the treatment.

\section{Results}

Of 150 patients with NLDO (174 eyes) were included in the current study. There were $77 / 150$ (51.3\%) were female, $73 / 150$ (48.7\%) were male patients. The mean age of patients was 22.3 ( 1 month- 8 years) months. Surgical procedures were performed in the right eyes of 62 patients $(41.3 \%)$, left eyes of $64(42.7 \%)$, and two eyes of 24 (16\%). The patients were divided into 4 groups according to their ages. Age groups, demographic features, surgical procedure and success rates of surgery are shown in Table 1 and Table 2.

Patients who did not respond to conservative treatment were treated with probing during the first 1 year (mean 10.6 months). Probing was performed in 61 eyes of 50 patients in the first group and $100 \%$ success was achieved. A one-month-old infant with dacryocystocele was treated with probing treatment without any conservative treatment response. In the second group, probing was performed in 77 eyes of 65 patients at 16 months of age, and $81.8 \%$ success was achieved. One patient in this group had nasolacrimal duct obstruction following noncongenital, traumatic canalicular injury. Two months after the canalicular repair, the patient underwent probing with epiphora, followed by silicone tube intubation. In the third group, probing was performed at around 36-month-age, in 23 eyes of 21 patients who had not had any interventional treatment before and 52\% success was achieved. In addition, silicone tube intubation was performed successfully in 3 of the patients who couldn't have been treated by probing. Probing was performed in 5 eyes of 12 patients in the fourth group, only one patient $(20 \%)$ was treated successfully, silicone tube intubation was performed in 5 eyes and passages were achieved in all eyes. In addition, two 8-year-old patients underwent endoscopic DCR and both were successful. In the fourth group, probing was performed at a mean of 26 months (24-48 months) and the success rate was low.

\section{Discussion}

Complaints related to the obstruction of the lacrimal system can be seen at any age. Congenital nasolacrimal canal obstruction is frequently seen in childhood and there are usually symptoms such as discharge and watering in the first month after birth ${ }^{6,11}$. After birth, it was shown that more than $30 \%$ of infants had obstructed the lacrimal system but about $4 \%$ were symptomatic $^{11}$. The membranous obstruction developing around the Hasner's valve is the most common cause of NLDO which has not yet completed its canalization. Additionally, since tear production does not mature at birth, so the symptoms appear after the first few weeks of tear production. It was reported that the obstruction was spontaneously opened and symptoms regressed until one year of age $\mathrm{e}^{3,6,7,12}$. Therefore, conservative treatment methods are recommended in the first year ${ }^{7}$. However, in the presence of additional pathologies such as mucocele, dacryocystocele, and severe infection, probing should be performed without waiting for one year ${ }^{7,8}$. There is no definite age range related to probing time in the literature. However, most ophthalmologists recommend conservative therapy. The massage of the lacrimal sac called Crigler massage is a widely adopted conservative treatment modality. This maneuver breaks the membranous obstruction by increasing the hydrostatic pressure. It was first introduced by Crigler in 1923. Crigler massage is a non-surgical treatment of CNLDO in infants below the age of one year. With this massage technique, a parent pushes to the bone with a finger, decompressing the top of the nasolacrimal sac, and then moves their finger downwards. However, in patients that cannot be achieved spontaneous opening or that cannot be opened with a message should be probing after one year ${ }^{2,6,7,13-14}$.

Zengin et $\mathrm{al}^{16}$. evaluated the probing success in 105 eyes of 84 patients (mean 16.4 months old) according to the age groups, the success rate of probing was $86.7 \%$ in patients between 12-24 months and $57.7 \%$ in those over 24 months. Besides, Esen et $\mathrm{al}^{8}$. evaluated the probing success in 66 eyes of 46 patients (mean 23.5 months old) according to the age groups, the success rate was reported to be $100 \%$ in the patients below 12 months, $80.9 \%$ in the $12-24$ months and $44.4 \%$ in those over 24 months. Kashkouli et $\mathrm{al}^{17}$. conducted a study with 169 eyes of 125 patients ( $1-5$ years old) and reported $89 \%$ success in the $13-24$ months and $72 \%$ success in those over 24 months and found a statistically significant decrease in probing success with increasing age. In the literature, it has been shown that early treatment therapy is more effective in many studies ${ }^{8,16-21}$. In our study, success was achieved in patients younger than 12 months with probing according to the literature. In the $12-24$ months group, $81.8 \%$ and $24-48$ months group achieved $52 \%$ success and were found compatible with previous studies. Despite the decrease in the success of age increases, probing in older patients who 
Table 1. Age groups, treatment methods, success rates and demographic characteristics of patients

\begin{tabular}{|c|c|c|c|c|}
\hline Age groups & Patient/Eye (n) & $\begin{array}{l}\text { Treatment method and } \\
\text { number of eyes (n,\%) }\end{array}$ & $\begin{array}{l}\text { Number of curative treatment } \\
\text { (n) / Success rate }(\%)\end{array}$ & Additional patology (n) \\
\hline \multirow[t]{2}{*}{$0-12$ months } & 50 & Probing & 61 eyes, $100 \%$ & Dacryocystocele *(1) \\
\hline & & $(61,100 \%)$ & & \\
\hline \multirow[t]{3}{*}{ 13-24 months } & 65 & Probing & 63 eyes, $81,8 \%$ & Traumatic \\
\hline & & & & injury **(1) \\
\hline & & $(77,100 \%)$ & & \\
\hline \multirow[t]{2}{*}{$25-48$ months } & 23 & Probing $(21,87,5 \%)$ & 11 eyes, $52,4 \%$ & - \\
\hline & & Silicone tube $(3,12,5 \%)$ & 3 eyes, $100 \%$ & \\
\hline \multirow{3}{*}{$\begin{array}{l}48 \text { months and } \\
\text { over }\end{array}$} & 12 & Probing $(5,41,66 \%)$ & 1 eyes, $20 \%$ & - \\
\hline & & Silicone tube $(5,41,66 \%)$ & 5 eyes, $100 \%$ & \\
\hline & & Endoscopic DCR $(2,16,66 \%)$ & 2 eyes, $100 \%$ & \\
\hline
\end{tabular}

* Probing was performed in the first month after birth.

**A patient in the 12-24 month group underwent canalicula repair and two months later she underwent probing and silicone tube intubation due to epiphora.

have not been probed before, or in a single operation, is probed up to three repetitions before performing more invasive procedures ${ }^{7}$. Okumuş et $\mathrm{al}^{7}$. have achieved a success rate of $81 \%$ in the first probe they applied at 12-24 months of age and $92 \%$ in the second and 94\% in the third. In fact, Honavar et $\mathrm{al}^{18}$. applied repeated probing after failed probing in 16 eyes of 60 patients at 24-month-age or more and they achieved success. Thus, it is emphasized that passages can be provided by probing before invasive surgery. We also applied to probing to our patients before invasive procedures.

Silicone tube intubation is recommended for patients older than 12 months who are considered to have complex NLDO or did not respond to conservative treatment, massage, and probing ${ }^{7,19,20}$. Okumuş et $\mathrm{al}^{7}$. performed silicone tube intubation in 39 patients older than 36 months and after waiting for at least 12 weeks, they removed the tube and achieved $72 \%$ success. In a study of 95 patients with nasolacrimal insufficiency with Down syndrome and without Down syndrome, Lim et $\mathrm{al}^{19}$. applied silicone tube intubation to patients between

Table 2. Demographic characteristics of the patients

\begin{tabular}{lcc}
\hline & \multicolumn{2}{c}{ Gender } \\
\cline { 2 - 3 } Age groups & Female (\%) & Male n(\%) \\
\hline $0-12$ months & $29(58)$ & $21(42)$ \\
$13-24$ months & $31(47.7)$ & $34(52.3)$ \\
$25-48$ months & $11(47.8)$ & $12(52.2)$ \\
48 months and over & $6(50)$ & $6(50)$
\end{tabular}

11 months and 9.5 years, the overall success rate was $85 \%$, the success rate was $89 \%$ for eyes in children with Down syndrome and the success rate was $85 \%$ for eyes in children without Down syndrome. Al-Faky et $\mathrm{al}^{20}$. reported 207 eyes of 181 children between 1 and 8 years old with CNLDO who had not undergone previous surgical treatment were included in the study. In this study, the success rate was $84.1 \%$ in 88 eyes underwent probing and the success rate was $89.2 \%$ in 93 eyes underwent bicanalicular silastic intubation. They reported that for simple CNLDO, there was a 94.2\% (65/69) success rate with probing and a $90.9 \%$ success rate with bicanalicular silastic intubation. However, in complex CNLDO, there was a $47.4 \%$ success rate with probing 
and an $85.2 \%$ success rate with bicanalicular silastic intubation. It was also reported that the success of bicanalicular silastic tube intubation in patients with complex CNLDO was approximately twice higher than the success of probing. However, in our study, silicone tube intubation was performed on the patients who were over 24 months and all the results were successful, yet the number of patients is insufficient. We had planned to investigate the study in more elderly pediatric patients and a large number of patients. Because of our retrospective study with limited files, we could not also demonstrate the causes of surgical failure. If there had been a large group of patients, our success could have reduced because of more complex blockages. Therefore, studies with a larger group of patients should be performed. On the other hand, in the literature, the causes of failure for probing have been reported as older age, bilateral congestion, canaliculus stenosis, anatomic pouch, nonmembranous NLDO, the NLD with bony protrusion, edematous NDL and the presence of severe obstruction findings ${ }^{5,12,21,22}$.

The main limitation of this retrospective study based on the accuracy and completeness of medical records. The majority of our study population consisted of patients younger than 24 months. Because our region is small and close to major centers, parents of pediatric patients avoiding more invasive interventions in our clinic could apply to major centers in order to get different opinions. Therefore, there were fewer elderly pediatric patients in our study for subsequent surgical procedures after the failed probing procedure. This did not allow us to try other methods in elderly pediatric patients who did not benefit from probing, this may be considered as a limitation for our current retrospective study. In the literature, DCR surgery is recommended for patients older than 7 years 7 . However, compared to external DCR, endoscopic DCR has fewer complications, shorter operative time, faster postoperative recovery, higher cosmetic success (no facial surgical scar), and higher operative success rate ${ }^{23}$. In our study, we performed a successful endoscopic DCR operation instead of applying external DCR to two patients (8 years old) due to its superior features. As for the other limiting factors involved in our study, a lower number of cases of the last two groups is also an important limiting factor. Except for the small number of cases performed with endoscopic imaging, there are some disadvantages such as the need for expensive instruments and equipment, endoscopic examination learning process, and the prolongation of the procedure.

\section{Conclusion}

Early diagnosis and timely treatment of CNLDO is the most important factor in increasing the success rate and has been proved by significant scientific evidence ${ }^{17,24-26}$. Since the success rate decreases after 2 years of age, many authors considers that age is a risk factor ${ }^{17,24-26}$. The preference and success rate of treatment are dependent on the age groups in pediatric patients with CNLDO. Probing is an effective treatment for CNLDO cases with minimal traumatic surgical intervention. Additionally, it is an effective treatment modality for CNLDO cases that do not respond to conservative treatment in the first years of life. The probing success decreases progressively with age, yet multiple probing is recommended prior to further invasive intervention is performed. However, in patients older than 36 months, the success rate of silicone tube intubation is higher than probing. Endoscopic or external DCR surgery may be more recommended for patients older than 7 years. On the other hand, endoscopic DCR may be preferred in elderly pediatric patients compared to external DCR due to fewer complications, shorter operative time, faster postoperative recovery, higher cosmetic success (no facial surgical scar), and higher operative success rate. Additionally, the early diagnosis and timely treatment of CNLDO is the most important step in increasing the success rate. Moreover, given the importance of early detection and treatment in CNLDO management, the importance of unmanned automated applications in ophthalmic healthcare settings is certain to increase day by day. Therefore, in the near future it will become a necessity to detect CNLDO and other ophthalmic diseases with unmanned automated applications in ophthalmic healthcare platforms ${ }^{27}$. Of note, in light of all the above information, we would like to emphasize the importance of early diagnosis and treatment in pediatric patients with CNLDO. Probing should not be delayed because with the increasing age, the success rate will decrease and the need for more aggressive and further treatments will be inevitable. However, prospective, longitudinal, randomized, comparative clinical studies are needed to reach agreement on the choice of procedure. 


\section{Financial Disclosure}

The authors received no specific funding for this work.

\section{Conflicts of Interests}

The authors report no conflicts of interest in this work.

\section{References}

1. Schnall BM. Pediatric nasolacrimal duct obstruction. Curr Opin Ophthalmol 2013;24(5):421-4.

2. Vagge A, Ferro Desideri L, Nucci P, Serafino M, Giannaccare G, Lembo A et al. Congenital nasolacrimal duct obstruction (CNLDO): a review. Diseases 2018;6(4). pii: E96.

3. MacEwen CJ, Young JD. Epiphora during the first year of life. Eye 1991;5:596-600.

4. Olitsky SE. Update on congenital nasolacrimal duct obstruction. Int Ophthalmol Clin 2014;54(3):1-7.

5. Petris C, Liu D. Probing for congenital nasolacrimal duct obstruction. Cochrane Database Syst Rev 2017;7: CD011109.

6. Young JD, MacEwen CJ. Managing congenital lacrimal obstruction in general practice. BMJ 1997;315:293-6.

7. Okumuş S, Erbağcı İ, Güngör K, Bekir N. Doğumsal nazolakrimal kanal tıkanıklığı olan hastalara yaş gruplarına göre uyguladığımız tedavi yöntemleri ve sonuçlarımız. Turkiye Klinikleri J Ophthalmol 2009;18(4):223-9.

8. Esen E, Özcan AA, Erdem E, Çiloğlu E, Şimdivar HG. Doğumsal nazolakrimal kanal tıkanıklığı tedavisinde sondalama yönteminin etkinliği. Turkiye Klinikleri J Ophthalmol 2012;42(5):342-5.

9. Robb RM. Success rates of nasolacrimal duct probing at time intervals after 1 year of age. Ophthalmology 1998;105:1307-9.

10. Broggi RJ. The treatment of congenital dacryostenosis. AMA Arch Ophthalmol 1959;61(1):30-6.

11. PaulTO,Shepherd R. Congenital nasolacrimal duct obstruction: natural history and the timing of optimal intervention. J Pediatr Ophthalmol Strabismus 1994;31(6):362-7.

12. Takahashi Y, Kakizaki H, Chan WO, Selva D. Management of congenital nasolacrimal duct obstruction. Acta Ophthalmol 2010;88:506-13.

13. Price HW. Dacryostenosis. J Pediatr 1947;30:300-5.

14. Petersen RA, Robb RM. The natural course of congenital obstruction of the nasolacrimal duct. J Pediatr Ophthalmol Strabismus 1978;15(4):246-50.
15. Cassady JV. Dacryocystitis of infancy. Trans Indiana Acad Ophthalmol Otolaryngol 1948;31:26-38.

16. Zengin N,Zengin MÖ. Doğumsal nazolakrimal kanal tıkanıklığı tedavisinde sondalama yönteminin etkinliği ve zamanlaması. İzmir Dr. Behçet Uz Çocuk Hast. Dergisi 2014;4(2):123-7.

17. Kashkouli MB, Beigi B, Parvaresh MM, Kassaee A, Tabatabaee $Z$. Late and very late initial probing for congenital nasolacrimal duct obstruction: what is the cause of failure? $\mathrm{Br} \mathrm{J}$ Ophthalmol 2003;87:1151-3.

18. Honavar SH, Prakash VE, Rao GN. Outcome of probing for congenital nasolacrimal duct obstruction in older children. Am J Ophthalmol 2000;130:42-8.

19. Lim CS, Martin F, Beckenham T, Cumming RG. Nasolacrimal duct obstruction in children: outcome of intubation. J AAPOS 2004;8(5):466-72.

20. Al-Faky YH, Mousa A, Kalantan H, Al-Otaibi A, Alodan $\mathrm{H}$, Alsuhaibani AH. A prospective, randomised comparison of probing versus bicanalicular silastic intubation for congenital nasolacrimal duct obstruction. Br J Ophthalmol 2015;99(2):246-50.

21. Repka MX, Chandler DL, Fishman DR, Goldblum TA, Holmes JM, Perla BD et al. Primary treatment of nasolacrimal duct obstruction with probing in children younger than 4 years. Ophthalmology 2008;115:577-84

22. Kashkouli MB, Kassaee A, Tabatabaee Z. Initial naso lacrimal duct probing in children under age 5: cure rate and factors affecting success. J AAPOS 2002;6:360-3.

23. Kaplan Y, Öz A, Gümüştaş Ç, Kara F. Primer endonazal endoskopik dakriyosistorinostomi sonuçlarımız. Van Tip Dergisi 2015;22(4):216-9.

24. Katowitz JA, Welsh MG. Timing of initial probing and irrigation in congenital nasolacrimal duct obstruction. Ophthalmology 1987;94(6):698-705.

25. Mannor GE, Rose GE, Frimpong-Ansah K, Ezra E. Factors affecting the success of nasolacrimal duct probing for congenital nasolacrimal duct obstruction. Am J Ophthalmol 1999;127(5):616-7.

26. Al-Faky $\mathrm{YH}, \mathrm{Al}$-Sobaie N, Mousa A, Al-Odan H, Al-Huthail $\mathrm{R}$, Osman $\mathrm{E}$ et al. Evaluation of treatment modalities and prognostic factors in children with congenital nasolacrimal duct obstruction. J AAPOS 2012;16(1):53-7.

27. Balyen L, Peto T. Promising artificial intelligence-machine learning-deep learning algorithms in ophthalmology. Asia Pac J Ophthalmol (Phila)2019;8(3):264-72. 